\title{
MANAGING DIGITAL TRANSFORMATION IN A BUSINESS AS A PART OF A LONG-TERM STRATEGY
}

\begin{abstract}
Анотація. Стаття присвячена одному з найважливіших стратегічних викликів сьогодення, з яким стикається бізнес-спільнота: управління інформатизованими даними, послуга, яка основується на взаємодії між підприємиями та їхніми активами. Трансформації стосуються реорганізації даних по «оцифрованим» клієнтам, управління клієнтськими базами, управління політичними та інституціональними викликами процесу диджиталізації. Доступ та використання інформатизованих баз даних викликає низку питань як до компаній, так і до їхніх клієнтів, які ми висвітили у запропонованому дослідженні.
\end{abstract}

Ключові слова: управління базою даних, цифровізація, інформаційна інновація та трансформація, інформатизована підприємницька діяльність

Summary. The paper covers one of the most important strategic challenges that modern business society faces nowadays: managing digitalization, a new value based on service managing the digital entrepreneurships and their processes of intermediating. The transformations concern the reorganization of digitalizing customers, managing organizational buyer alliances, managing the political and institutional challenges of digitalization. The access to and the use of a big data poses some questions for both companies and their customers that we have lighted in the proposed research.

Key words: managing big data, digitalization, digital innovation and transformation, digital entrepreneurships.

DOI : 10.33783/1977-4167-2019-45-1-59-63

Articulation of the problem. The role of digital technology in business and society is rapidly shifting from being a driver of marginal efficiency to an enabler of fundamental innovation and disruption in many industrial sectors, such as media, information and communication industries, and many more. The economic, societal, and business implications of digitalization are contested and raise serious questions about the wider impact of digital transformation. Digitalization affects all private and public operations, as well as the internal and external workings of any operation. Digitalization is the major driving force behind sweeping large-scale transformations in a multitude of industries.

Analysis of the recent researches and publications. The issues of digitalization process are actually opened up for many network interdependencies that cross industry borders and require the technical development for the formation of new business ventures. These hot points of topic are analyzed in works of P. Andersson, S. Movin, M. Mähring, R. Teigland and others [1]. The issues of an individual company development are considered in such a context by Markendahl, J. and Mattsson, L. G. [2], they designed and proposed the business model construction and independent devel-

(C) Г. І. Фролова, В. В. Білоусова, В. Ф. Столяров, 2018 opment of a sustainable digital transformation. The good examples of such a model implementation are described in many resources, including Berman, S. J. [3], Ehret, M. and Wirtz J. [4] and others. Westerman, G. and Bonnet, D. [5] showed in their research the ways of implementing the ideas of «smart cities» based upon new digital infrastructures, means that different private as well as public actors may prefer other designs of the model. Conflicts between actors with different business models need to be addressed. For a digital service innovation of this magnitude, many uncertainties will emerge, thus, challenging traditional roles and positions. And all of the authors noted that both young digitalizing firms and established businesses face when they seek to collaborate with one another in order to engage in digital transformation processes and underlined that such cross-industry collaborations also enable firms to accelerate innovation and create more competitive market positions.

The purpose of current research is aimed to light out the key challenges in today's business organizations, in the quest to adapt to ever-evolving business environments. The paper examines new demands and behaviors, and discusses how businesses need to adapt and re-organize in order to bridge the gap to the digital

Бібліографія ДСТУ 8302:2015:

Фролова Г. І., Білоусова В. В., Столяров В. Ф. Управління ІТ-трансформацією бізнесу як складовою довгострокової стратегії. Вісник Бердянського університету менеджменту і бізнесу. 2019. № 1 (45). С. $59-63$.

References (APA):

Frolova, H. I., Bilousova, V. V., Stoliarov, V. F. (2019). Upravlinnia IT-transformatsiieiu biznesuyakskladovoiu dovhostrokovoi stratehii [Managing digital transformation in a business as a part of a long-term strategy]. Visnyk Berdianskoho universytetu menedzhmentu i biznesu, 1 (45), 59-63 (in Ukr.). 
customer. These visions and actions on digitalization can help corporations and organizations discover new ways of earning money and delivering value.

Presentation of the main research material. In many sectors, digitalization has become connected to transitions from product to service provision or shifting toward a service dominant logic. This has also become one of the major managerial challenges in digitalization processes: one that often requires new organizational principles, structures, and customer interaction processes. Business models change from transaction to relationship-oriented, which means that new sets of capabilities will have to be developed: such as organization structures, metrics, marketing and sales incentives, and more. Three possible service innovations can be seen in the following examples: Philips launching its concept of «lighting as a service»; Volvo is marketing its «connected several strategic challenges of digital innovation and transformation vehicle» based upon new digital infrastructures; and, public transportation company, Nobina is moving toward «mobility-as-aservice» for city travellers instead of bus operations. These innovations involve many knowledge areas, new digital technologies and platforms, and actors from several industries in new partnerships. Such digital service innovations may be new, in terms of how individual services are connected to each other (bundled or unbundled), the role of different actors (including the users), the organization and the distribution of services (as well as the price and payment for services). Based on the data we have seen and reported how cooperative and competitive relationships in business practice change when different knowledge areas and industries are involved in such digital service innovations. Shifting from product to service-based business models when going through a digital transformation means that uncertainty and complexity need to be acknowledged. Moreover, the value of the new digitallybased service for a user may be more or less difficult to perceive and evaluate during the transformation [1].

The next important point is managing big data by creating new value based on services received from digitalization. According to the info from three managers interviewed in 2016 in an ongoing research project on digitalization processes in different sectors of the networked society, the problem area focuses on strategic challenge connected to digital transformation. They notified that one important question is if they should build their own internal big data analytical capabilities, like some leading companies that have created specific units and business focused on this, or if they should outsource parts of big data operations to their partners. They also added that one of the strategic issues they are struggling with in their ongoing digitalization concerns their future approach to big data. There is a business opportunity in this, but one of the tricky issues concerns the fact that the products are strongly connected to a number of competing compa- nies' products. Big data analyses for the end user of these systems is of less value if the analyses do not involve data from all products. This is a new situation of competition and cooperation emerging [1; 23]. In an article published within our ongoing research the authors argue: «We find it useful to introduce elements from methodology, specifically including material objects as actors and we acknowledge the formative role of technology for overlapping and intermediating in industrial networks.» [2; 92]. A three-year research project on digitalization processes ending in 2017: Renewal of the Service Society [2; s.93].

The other issue is managing digitalization and service transformation that means the shifting from product to service-based business models. In many sectors, digitalization has become connected to transitions from product to service provision or, in the words of Vargo \& Lusch (2004), shifting toward a service dominant logic. This has also become one of the major managerial challenges in digitalization processes: one that often requires new organizational principles, structures, and customer interaction processes. Business models change from transaction to relationshiporiented, which means that new sets of capabilities will have to be developed: such as organization structures, metrics, marketing and sales incentives, and more. Three possible service innovations can be seen in the following examples: Philips launching its concept of «lighting as a service»; Volvo is marketing its digital innovation and transformation vehicle based upon new digital infrastructures; and, public transportation company Nobina moving toward «mobility-asa-service» for city travellers instead of bus operations. These innovations involve many knowledge areas, new digital technologies and platforms, and actors from several industries in new partnerships. Such digital service innovations may be new, in terms of how individual services are connected to each other (bundled or unbundled), the role of different actors (including the users), the organization and the distribution of services (as well as the price and payment for services). We have seen and reported (Andersson \& Mattsson 2015) how cooperative and competitive relationships in business practice change when different knowledge areas and industries are involved in such digital service innovations. Shifting from product to service-based business models when going through a digital transformation means that uncertainty and complexity need to be acknowledged. Moreover, the value of the new digitallybased service for a user may be more or less difficult to perceive and evaluate during the transformation.

The problem to manage the new digital entrepreneurs and their rapid processes of intermediating is going rapidly. There is a tendency to draw a great deal of attention to the steps and moves of the so-called Unicorns and successful digital start-ups when discussing and analyzing digital transformation. In reality, digital transformation processes in all sectors involve a wide 
array of different relationships between both young and established incumbent firms being dependent upon each other and being part of the same transformation. Digital transformation is a collaborative innovation process in which small and large companies create joint strategic partnerships. The small digital start-ups may take advantage of the fact that many of them are digital from the start and may also possess a scalable business model from the outset. They are often in need of access to the established incumbents' advantages, however: in terms of financial resources, established cooperation networks, experiences, regulatory knowledge, and so on. In some cases, they can rapidly scale successful digitalization experiments across multiple markets. An example can be seen in the service sector. New digital actors, such as Booking. com and Tripadvisor, have created new intermediate positions in a short period of time between hotels (including big global hotel chains) and customers: where the former struggles to attract hotel customers back to the hotels' own web/booking sites. As a result of digitalization processes, similar intermediation can be seen in other service industries, thus, challenging the incumbents regarding who is going to have most of the direct contact with the customers. As a previous study stated: «... service innovation processes might require, or stimulate, changes in intermediation - sometimes also the entry of new actors as intermediaries» [1; s.56]. One company expressed the process as going in both directions: that is to say, embracing both dis-intermediation and re-intermediation processes that increased usage of ICT has led to a complex and dynamic process of disintermediation, as producers are able to generate direct sales and creators can directly distribute their work online. Telecom and IT players, meanwhile, create a move toward 31 strategic challenges of digital innovation 're-intermediation,' allowing smaller companies that may not have large marketing budgets to participate in the market. The challenge of managing the new digital entrepreneurs and their rapid processes of intermediating has a mirror effect; the digital startups need to embed their business in established network settings by relating to incumbents. No business is an island.

There is a problem of reorganization of digitalization customers in order to manage organizational buyer alliances. The digitalization of companies and industries also affects the buyer side. Purchasing power moves to executives outside of regular purchasing and IT departments and functions. Digitization brings a more permanent change to the ICT investment and buying processes. In turn, this creates a more complex sales environment for technology providers engaged in their customers' digitalization processes. Furthermore, large-scale digitalization processes - such as investments in «Smart cities» - create new and very complex buying situations. Complex constellations of both public and private organizations need to engage in the creation of functioning buyer constellations in order for large-scale digitalization processes - such as smart city projects - to move from idea to pilot, and then to large-scale implementation. Successful examples, such as the city of Dubai, can be explained by the fact that constellations on the buyers' side have been created and engaged in the process. The growing influence of joint business and public buyer constellations in purchasing decisions when digitalizing also constitutes a major challenge for the supply side. Providers of digital solutions will need to support the creation of functioning buyer constellations, thus, creating new go-to-market models that meet these organizational challenges on the buyers' side.

We also should pay a big attention to managing the political and institutional challenges of digitalization. Digitalization, in general, and the access to and use of big data, in particular, pose a number of challenges for both companies and policy makers. As one manager in health care expressed it: «One of the biggest challenges for us right now is how to relate to policy makers and policy making [3; s.54].» Nowadays there is a lack of 33 strategic challenges of digital innovation and transformation policy making - when it comes to digitalization, in general, and issues concerning patient data, in particular. Understanding how to handle these new strategic issues and how to influence politicians and policymakers are two of our major concerns. Addressing privacy and security issues will become paramount as more data increasingly travels across boundaries for various purposes and as a result of increased digitalization. Security issues and intellectual property issues are becoming part of companies' data strategies, yet it is perhaps becoming more importantly a privacy and trust issue when it concerns customers and other stakeholders. Meanwhile, one of the strategic challenges for companies in many digitalizing sectors is how to influence policy makers, so the choices they make also help individual firms in their quest to capture value from using big data. For digitalizing companies, it is a matter of complying with the role that policy makers have of developing policies that balance the interests of companies that want to create value from data and citizens who wish to protect their privacy and security. This new situation for companies is often accentuated by the fact that one of the most important enablers of value creation from big data combines data from multiple sources. This is a new situation in many sectors and digital data policies are still often lacking or need to be adapted. Still, this has become one of the major strategic challenges for many companies: the way in which to relate to - and sometimes influence - new policy-making. The ownership, access, collection, storage, use, and dissemination of information require rules and policies; companies and public organization tend to become highly involved in these processes.

Digitalization Challenges are connected to the focus of the ten challenges of digital transformation 
is different: some are more closely connected; some are not. Those that are concern technology: for example, platforms and big data management and user orientation - such as big data analyses, user-centric and user-network drove actions. Several managerial challenges are business-model related: creating new cooperate business models and shifting to servicebased business models; some of these also connect to broader ecosystem-related challenges for digitalizing companies; 4 For example, both public and private organizations need to interpret and relate to various new principles: for example, OECD's eight Privacy Principles, which concern: Collection Limitation, Data Quality, Purpose Specification, Use Limitation, Security Safeguards, Openness, Individual Participation, and Accountability.

Creating new business across industry boundaries and managing new forms of buyer/user constellations. A digital transformation challenge for an incumbent firm seldom comes alone. The medical technology company to which we referred in the introduction began one part of its digital transformation with a delimited interest in how to manage the big data generated from the use of its intensive care machines. Successively, major business model issues emerged: cooperation or competition with other machine suppliers and users: doctors, hospital administration units, and other related issues. Seeing how firms in various sectors take different initiatives into digital transformation, we can see that digital transformation steps often lead to new digitalization challenges. Managers need to cope with the fact that digitalization challenges do not come alone. We can assume by building upon our first insights into this issue when going into the fifteen business areas of digital transformation, that companies take different paths in their digital transformation processes.

There are differences with regard to initial drivers and managerial problems, as well as when and the way in which these connected challenges are handled. Hence, the emphasis shifts over time. Technical platform issues in this digital transformation might dominate a certain period; more attention could be given to user-centric issues and the processes of business modeling or creating functioning cooperation between involved stakeholders in the emerging ecosystems might dominate the other stages. Incumbents in many industries have begun their digitalization journeys; the starting point creates different digital transformation paths in different industries and in different organizational contexts. The management of digital transformation should not be seen as purely an intra-organizational or operational issue. Instead, it is a strategic and societal issue, which is often a challenge of highest priority. As seen in Table 1, the studies and cases of digital transformation, however, all reveal that the ten strategic challenges are connected to big internal challenges and tensions within the organizations.
There are some tools to change management challenges in digitalization. Many incumbent organizations are not prepared for digital transformation. A big challenge is the actual change process. One report describes three ways in which organizations seem to approach the change management challenge when digitalizing.

The first is a direct approach: that is to say, transforming existing business processes. Initiatives can come from, and within, various parts of an organization: marketing, supply chain, production, and operations. They can also be connected to a number of partnerships of the organization. One of the many challenges with the direct approach is how to coordinate different initiatives and how to engage the entire organization.

The second approach starts by creating an autonomous «digital unit» free from corporate legacy and standardized business processes. When «skunk works» unit functions as a start-up with no learning barriers or aversions to risk the second approach has a niche focus upon building new digital models.

The third change approach builds a parallel digital business, which is a parallel business aimed at repositioning the existing enterprise as a start-up geared towards digitalization. This becomes a sort of incubator aimed at delivering new business models and insights that can be leveraged by the traditional organization.

Overall, there are multiple ways to begin removing barriers to digitalization and to learn from the change processes within organizations. Irrespective of the change management principle, one of the major challenges is how to digitally transform the entire organization and how to coordinate different change initiatives. Traditional mindsets, practices, and resources can be difficult to adapt. Developing new (digital) mindsets, practices, and resources on every level, and within every function, is often perceived as being a difficult and long-term change management issue.

Conclusion. There is widespread consensus among management consultants on digital platforms with a new pillar of profitable growth or even a fourth industrial revolution. These ideas are trickling down into business schools and into buzzword-driven academic business research. While citing more or less fanciful examples of digital platforms to illustrate the potential for innovative value creation concerning value capture, the literature tends to be less distinct, or even conceptually misleading. We described different general paths of digital transformation building upon our insight from the fifteen areas of digital transformation, arguing that there are strong overlaps between them: in terms of the accompanying managerial issues that are involved and managed. For example, big data problems and issues appear in many of the studied business contexts. There are also differences with regard to initial drivers and managerial problems, as well as 
when and the way in which external strategic challenges and internal operational challenges are handled. In these terms, the digital transformation paths are always unique, while the overall external and internal digital transformation challenges are very similar across industries and organizations.

\section{Лiтература}

1. Andersson, P., Movin, S., Mähring, M., Teigland, R. Managing digital transformation. Stockholm, SSE Institute for Research, Stockholm School of Economics, 2018, 1, 344 p. (Eng.).

2. Andersson, P., Markendahl, J. and Mattsson, L. G. (2011). Technical development and the formation of new business ventures - the case of new mobile payment and ticketing services. The IMP Journal, 1 (5), 23-41 (Eng.).

3. Westerman, G and Bonnet, D. (2015). Revamping Your Business Through Digital Transformation. MIT Sloan Management Review, Spring 2015, 2-5 (Eng.).

4. Ehret, M. and Wirtz, J. (2017). Unlocking value from machines: business models and the industrial internet of things. Journal of Marketing Management, 33:1-2, 111-130 (Eng.).
5. Berman, S. J. (2012). Digital transformation: opportunities to create new business models. Strategy \& Leadership, 2 (40), 16-24 (Eng.).

\section{References}

1. Andersson, P., Movin, S., Mähring, M., Teigland, R. Managing digital transformation. Stockholm, SSE Institute for Research, Stockholm School of Economics, 2018, 1, 344 p. (Eng.).

2. Andersson, P., Markendahl, J. and Mattsson, L. G. (2011). Technical development and the formation of new business ventures - the case of new mobile payment and ticketing services. The IMP Journal, 1 (5), 23-41 (Eng.).

3. Westerman, G and Bonnet, D. (2015). Revamping Your Business Through Digital Transformation. MIT Sloan Management Review, Spring 2015, 2-5 (Eng.).

4. Ehret, M. and Wirtz, J. (2017). Unlocking value from machines: business models and the industrial internet of things. Journal of Marketing Management, 33:1-2, 111-130 (Eng.).

5. Berman, S. J. (2012). Digital transformation: opportunities to create new business models. Strategy \& Leadership, 2 (40), 16-24 (Eng.). 